\title{
Kajian Ekoteologis tentang Konsep tanah dalam Perjanjian Lama dan Implikasinya bagi Pemeliharaan Tanah
}

\author{
Roy Charly H.P. Sipahutar \\ Institut Agama Kristen Negeri Tarutung, Sumatera Utara \\ roycharlygpp@gmail.com
}

\begin{abstract}
Abstact: This article is an echotheological study of the basis of Israel's election and agreement as God's people in relation to the ownership of the Land of Canaan. Israel as a nation and chosen people certainly have a duty as a blessing to others. This study departs from the meaning of the agreement affirmed on Mount Sinai, namely that God wants Israel to live in loyalty and always care for social life. The agreement was subsequently implemented in the form of the giving of the land of Canaan as another symbol. The promised land management is not only for the benefit of the people of Israel, but also must have a social dimension for the poor, oppressed, and marginalized, this is the ethical basis of Israel's life as God's people. Land must be cultivated as a source of God's peace (syalom) for all His creatures, because only in this way can they breathe in the covenant with the Divine, God the Almighty. Furthermore, at the end of this paper it will be concluded that human beings as God's representatives do not mean acting according to their own desires, because humans must always remember that everything will be accounted for back to God.
\end{abstract}

Keywords: echotheological; Israel; Old Testament; promised land

\begin{abstract}
Abstrak: Artikel ini adalah sebuah kajian ekoteologis mengenai dasar pemilihan dan perjanjian Israel sebagai umat Allah dalam hubungannya dengan kepemilikan Tanah Kanaan. Israel sebagai bangsa dan umat pilihan tentunya memiliki tugas sebagai berkat bagi orang lain. Kajian ini berangkat dari makna perjanjian yang ditegaskan di Gunung Sinai, yaitu bahwa Tuhan menginginkan Israel hidup dalam kesetiaan dan selalu peduli pada kehidupan sosial. Perjanjian itu selanjutnya diemplementasikan dalam bentuk pemberian tanah Kanaan sebagai simbol yang lain. Pengelolaan tanah yang dijanjikan tidak hanya untuk kepentingan rakyat Israel, tetapi juga harus memiliki dimensi sosial untuk orang miskin, tertindas, dan terpinggirkan, hal tersebutlah yang menjadi dasar etis kehidupan Israel sebagai umat Allah. Tanah harus diusahakan sebagai sumber kedamaian Allah (syalom) untuk semua makhluk-Nya, karena hanya dengan cara ini mereka dapat bernafas dalam ikatan perjanjian dengan yang Ilahi, Allah Yang Maha Kuasa. Selanjutnya, pada bagian akhir tulisan ini akan disimpulkan bahwa manusia sebagai wakil Allah bukan berarti berbuat sesuai dengan keinginan dirinya sendiri, karena manusia harus selalu mengingat bahwa segala sesuatu akan dipertanggungjawabkan kembali kepada Allah.
\end{abstract}

Kata kunci: ekoteologis; Israel; Perjanjian Lama; tanah perjanjian

\begin{tabular}{llll}
\hline Article History : & Received: 31-03-2019 & Revised: 28-10-2019 & Accepted: 05-12-2019
\end{tabular}




\section{Pendahuluan}

Kisah Perjanjian Lama tentang pemilihan dan perjanjian dimulai dengan janji-janji Allah kepada bapa leluhur, Abraham. Unsur yang pokok dari janji itu, sebagaimana dinyatakan dan diulang dalam cerita-cerita bapa leluhur adalah bahwa Allah akan memberikan tanah kepada Abraham dan keturunannya. Tanah tersebut menjadi salah satu ciri yang menonjol dari rangkaian cerita dan kehidupan di dalam Perjanjian Lama. Tapi tampaknya tema tanah ini tidak demikian mendapatkan perhatian yang begitu besar ketika para sarjana berbicara tentang Israel dalam hubungannya sebagai umat perjanjian dan umat yang terpilih, Hukum Taurat adalah yang terutama. Contohnya Dyrness membahas banyak tema, tidak menyinggung tentang pemberian tanah sebagai suatu yang penting. ${ }^{1}$

Tanah merupakan topik penting dalam Perjanjian Lama, tetapi sedikit sekali ahli Biblika yang membahasnya secara komprehensif. Padahal jelas tidak sedikit teks-teks Perjanjian Lama menyinggung secara langsung mengenai isu tanah ini, pemulihan tanah pada tahun Sabat, tanah sebagi perjanjian Allah dengan Israel (Yos 21), dan tanah sebagai simbol kebaikan Tuhan (bnd. Ul 6). Kepentingan lain pembahasan tema tanah ini adalah demi alasan teologis dan aktualisasi problem pengolahan alam yang di luar batas kewajaran pada beberapa dasawarsa terakhir ini. Eksploitasi yang berlebihan yang seolah-olah tidak lagi memiliki pertimbangan etis dan kewajaran. Wright melukiskan tentang kerangka etika Perjanjian Lama (Allah, Manusia, dan Tanah) sebagai sebuah segi tiga sama sisi dengan sudut yang saling berkaitan satu dengan yang lainnya. ${ }^{2}$ Etika Perjanjian Lama dibangun berdasarkan pemahaman Israel akan keberadaan mereka sebagai suatu umat, hubungan mereka dengan Allah dan lingkungan fisis mereka (tanah). Setiap "sudut" adalah bagian yang terintegrasi untuk melihat gambaran yang utuh tentang etika Perjanjian Lama. Allah sebagai dasar Teologis, Manusia sebagai gerak sosial dan Tanah adalah ajang pergumulan umat. Tulisan ini akan mengeksplor bagaimana makna pemberian dan pendudukan tanah dalam Perjanjian Lama dengan tujuan dapat menjadi dasar ekoteologis pengolahan tanah serta bagaimana hidup di atasnya dengan bermartabat.

\section{Metode Penelitian}

Metode yang digunakan dalam penelitian ini adalah kualitatif dengan kajian konteks Perjanjian Lama. Tulisan ini adalah suatu analisis ekoteologis yang mengedepankan pemberian tanah Kanaan sebagai simbolisasi lain atas perjanjian Allah dengan Israel. Objek penelitian adalah teks-teks Perjanjian Lama yang berkaitan erat dengan tema

\footnotetext{
${ }^{1}$ Lihat William Dyrness, Tema-tema dalam Teologi Perjanjian Lama Terjemahan Tanpa Nama (Malang: Gandum Mas, 2014), 95-107. Durdica Stanojevic, The Promised Land: Hermeneutical And Theological Approach. Contemporary Ecotheological Readings, (Thessaloniki: Aristotle University Of Thessaloniki, 2014), 48.

${ }^{2}$ Christopher Wright, Hidup Sebagai Umat Allah Terjemahan Liem Sien Kie (Jakarta: BPK Gunung Mulia, 1995), 17.
} 
perjanjian khususnya yang merujuk kepada pemberian, pendudukan dan pemanfaatan Tanah Perjanjian. Pemaparan akan dimulai dari keistimewaan Israel sebagai Umat dan Bangsa Pilihan yang nantinya sebagai jalan masuk untuk melihat bahwa keseluruhan perjalanan mereka diikat oleh suatu perjanjian yang khas pula. Perjanjian membutuhkan pengikat, dan tanah Kanaan adalah simbolisasi yang sempurna sebagai pengikat antara Allah dan Israel. Makna teologis pemberian tanah Kanaan akhirnya sebagai dasar refleksi bagi teologi ekologis di bagian akhir tulisan ini.

\section{Hasil dan Pembahasan}

\section{Pemilihan Israel: Sebuah Bangsa dan Umat}

Israel sebagai bangsa ataupun sebagai sebuah komunitas agama, sesungguhnya sulit menemukan pengetahuan yang sempurna mengenai hal ini. Kesulitan ini bukan hanya menjadi milik peneliti yang ingin menyelidikinya saat ini, tetapi juga bagi bangsa Israel itu sendiri. ${ }^{3}$ Pemberian nama baru ditegaskan di Bethel dalam Kejadian 35:10 di mana Allah Yang Mahakuasa menampakkan diri kepada Yakub dan mengatakan, "Namamu Yakub; mulai sekarang namamu bukan lagi Yakub, melainkan Israel, itulah yang akan menjadi namamu". Sejak itu sekali-kali nama Israel dipakai di seluruh Perjanjian Lama sebagai sinonim dari Yakub. ${ }^{4}$ Mungkin karena hal inilah keturunan Yakub nantinya sering sekali dipanggil dengan sebutan sebagai anak-anak Israel atau bangsa Israel.

Acuan paling dini penunjukan kepada bangsa Israel sebagai suatu "bangsa" dalam berita non-Israel terdapat dalam prasasti Merenptah, raja Mesir, kira-kira tahun 1220 sM. ${ }^{5}$ dan juga terdapat dalam prasasti-prasasti Salamaneser III dari Asyur yang berulang-ulang menyebut nama Israel, tahun 853 sM. 6 Acuan prasasti Merenptah sekitar tahun 1220 sM. tersebut dapatlah disebutkan sebagai praktik awal sejarah nasional bangsa Israel, sebagai awal pergerakan mereka akan kesadaran untuk keluar dari perbudakan Mesir selama lebih dari 430 tahun (Kel 12:40). ${ }^{7}$

Barth menerangkan lebih jauh bahwa peristiwa keluaran dari Mesir adalah sebagai dasar berdirinya dan permulaan umat Israel. Keluaran sebagai fakta dasar nampak dalam Keluaran 4:22-23; Mazmur 66:5-6; 74:12-15. Dan juga beberapa nas yang menghubungkan peristiwa kemenangan Allah di Laut Teberau dengan kemenanganNya pada permulaan dunia (Mzm 89:9-13; Yes 51:9-10). ${ }^{8}$ Semua nas ini menunjuk pada satu arah yang jelas, bahwa perbuatan Allah yang membawa orang Israel keluar dari tempat perbudakan di Mesir maka dengan itu sekaligus Allah memateraikan mereka sebagai bangsa dan umat pilihan-Nya, dan hendak mewujudkan janji pemilikan tanah

\footnotetext{
${ }^{3}$ Th. C. Vriezen, Agama Israel Kuno Terjemahan I.J.Cairns (Jakarta: BPK Gunung Mulia, 2000$), 2$.

${ }^{4}$ H.L. Elisson, The Message of the Old Testament (Michigan: Grand Rapids, 1969), 28-29.

${ }^{5}$ Gerhard von Rad, "Israel", dalam: Gerhard Kittel (ed.), Theological Dictionary of the New Testament Vol.IV (Michigan: Grand Rapids, 1974), 356-357.

6 F.F. Bruce, "Israel", dalam: J.D. Douglas (ed.), Ensiklopedi Alkitab Masa Kini 1 (Jakarta: Yayasan Komunikasi Bina Kasih/OMF, 2000), 447.

7 R.J.D. Knauth, "Israelites", dalam: Desmond Alexander dan David W Baker (eds.), Dictionary Old Testament: Pentateuch (Leichester: Intervarsity Press, 2008), 456.

${ }^{8}$ Christoph Barth, Theologia Perjanjian Lama 1 (Jakarta: BPK Gunung Mulia, 2008), 113.
} 
sebagai "materai" perjanjian tersebut. ${ }^{9}$ Bahkan Wismoady Wahono lebih gamblang mengatakan bahwa peristiwa keluaran Israel dari Mesir adalah merupakan hal yang paling pokok dalam pembentukan iman Israel sebagai umat Allah. Keterangan yang sangat karateristis bagi Allah Perjanjian Lama adalah sebagi berikut: "Akulah Tuhan, Allahmu, yang mengeluarkan engkau dari tanah Mesir". Allah yang seperti itulah Allah yang selalu diberitakan oleh para nabi. ${ }^{10}$ Pengangkatan Israel sebagai umat Allah adalah sebuah kisah yang penuh kegembiraan mengenai perlindungan Allah, menciptakan sebuah perjanjian yang kekal antara Allah Yang Maha Kuasa sebagai Bapa dengan Umat Israel sebagi anak yang terkasih. ${ }^{11}$ Dalam perjanjian ini hadir ketentuan-ketentuan yang pasti. Di sini hal berpegang pada perjanjian itu diperluas artinya menjadi tanggapan ketaatan Israel pada inisiatif Allah.

Istilah umat Allah merupakan rumusan yang cukup muda. Rumusan itu ditemukan dalam Yeremia 11:4; 31:33; Yehezkiel 36:28, dan dalam tradisi Tora yang kemudian, misalnya Ulangan 26:17-19; Imamat 26:12. Tetapi rumusan ini mencerminkan pengertian yang mendalam pada tradisi yang sudah lama ada, yakni tradisi hubungan Allah dengan Israel dalam perjanjian. ${ }^{12}$ Dalam hal ini, tentu tidak terlepas dari kesinambungan janji Allah yang telah dimulai dari pemanggilan Abraham (Kej 12:1-3) sebagai awal rencana keselamatan yang Tuhan akan lakukan melalui keturunan Abraham. Rumusan akan perjanjian inilah yang meyakini bangsa Israel bahwa mereka adalah sebagai bangsa yang hanya milik Tuhan semata. Maka dalam perjalanannya, kejahatan Israel yang pokok tidak lain kecuali mengingkari hubungan perjanjian ini.

Pada zaman kerajaan Daud dan Salomo, nama Israel adalah sebuah ungkapan yang khusus bagi sebuah kawasan teritorial yang merdeka yang sering juga disebut "House of Judah (Kerajaan/Rumah Yehuda)", hal ini dapat dimengerti bagaimana Daud "Sang Raja Yehuda" memerintah seluruh kawasan Israel termasuk Hebron (2 Sam 5:1-5). ${ }^{13}$ Namun sejarah selanjutnya, karena kebijakan pajak yang sangat tinggi yang diterapkan oleh Salomo, raja yang selanjutnya, maka pemerintahan Israel menjadi melemah, kebanyakan dari bangsa-bangsa yang ditundukkan sebelumnya memperoleh kembali kemerdekaan mereka. Sedangkan suku-suku Israel sendiri pecah menjadi dua kerajaan, yakni di utara kerajaan Israel yang meninggalkan kesetiaannya terhadap takhta Daud, dan yang di selatan kerajaan Yehuda, meliputi wilayah suku Yehuda dan Benyamin, di mana keturunan Daud dan Salomo terus memerintah di ibukota Yerusalem.

\section{Perjanjian}

Perjanjian (berith) adalah bentuk kata kerja feminim dari kata benda "brh" yang berarti "makan" atau "makan malam". Kata ini mungkin menunjuk kepada persembahan daging dalam sebuah ritual hubungan perjanjian. Mungkin juga identik dengan kata birith yang

\footnotetext{
${ }^{9}$ Bruce K. Waltke, An Old Testament Theology (Michigan: Grand Rapids, 2007), 327.

${ }^{10}$ Wismoady Wahono, Di Sini Kutemukan (Jakarta: BPK Gunung Mulia, 2000), 107.

${ }^{11}$ William Dyrness, Tema-tema dalam Teologi Perjanjian Lama, 100-101.

12 Darmawijaya, Jiwa dan Semangat Perjanjian Lama ( Yogyakarta: Kanisius, 1992), 69.

${ }^{13}$ H.J. Zobel, "Yisra'el", 406.
} 
berarti "di antara" (among, between), menyatakan terjadi sesuatu hal di antara dua hal yang berbeda. Berith bukanlah persetujuan atau perundingan antara dua belah pihak, tetapi berarti sebuah perintah (commanded), bersinonim dengan hukum ataupun juga undang-undang. ${ }^{14}$

Sejak semula, para bapak leluhur memandang Allah sebagai Allah dari manusia, dan bukan sebagai Allah dari tempat-tempat tertentu. Hanya sekali saja Allah disebut sebagai "Allah dari Bethel" (Kej 31:13) untuk mengingatkan Yakub bahwa Allah akan menyertainya kemanapun ia pergi. Mudah dimengerti mengapa bangsa-bangsa pengembara yang terus-menerus berpindah-pindah itu senantiasa menghubungkan dewa-dewanya dengan bangsa-bangsa tertentu dan bukan dengan tempat-tempat tertentu. Dalam hal semacam inilah hubungan antara dewa-dewa dengan para penyembahnya mengambil bentuk perjanjian. ${ }^{15}$ Persekutuan perjanjian adalah suatu persetujuan dimana para penyembah berjanji untuk tetap taat dan setia kepada dewa atau ilah sembahannya sebagai imbalan atas berkat dan perlindungan yang mereka anggap diberikan oleh para dewa/ilah tersebut.

Perjanjian adalah suatu janji sungguh-sungguh yang diikat oleh sumpah, yang dapat merupakan ucapan lisan ataupun tindakan simbolis. Meskipun dalam Perjanjian Lama secara khusus bertumpu pada perjanjian di Sinai, jangkauannya dimulai dari penciptaan sampai kepada para nabi. Perjanjian adalah inti pengertian orang Ibrani tentang hubungan mereka dengan Allah. ${ }^{16}$ Berith merupakan sarana Allah untuk menyatakan diri kepada umat-Nya. Kehidupan bangsa Israel memiliki arti yang khusus; sejarah sendiri diarahkan dan menjadi berarti. ${ }^{17}$ Namun Perjanjian ini sesungguhnya juga tidak membuat garis pemisah yang jelas untuk melarang orang asing masuk ke dalamnya tetapi selalu memberikan kesempatan orang lain masuk ke dalamnya. ${ }^{18}$

Kejadian 12-50 adalah sejarah pengadaan perjanjian Abraham. Kitab Keluaran sampai kitab Ulangan adalah sejarah mengenai penetapan perjanjian di Sinai. Kitab Yosua adalah catatan mengenai kesetiaan Allah terhadap perjanjian itu, sedangkan kitab Hakim-hakim adalah catatan mengenai ketidaksetiaan Israel terhadap perjanjian tersebut. Kitab Samuel dan Raja-raja adalah sejarah perjanjian kerajaan (Perjanjian Daud). Perjanjian itu sebagai rencana Allah terlihat dengan lebih jelas daripada orangorang yang terlibat dari generasi ke generasi.

Khususnya bagi para nabi, Hosea, Yeremia, dan Yehezkiel, melihat kekhususan kesetiaan dalam hubungan perjanjian antara Allah dengan Israel seperti hubungan yang istimewa antara seorang suami dengan sang isteri. Dimana keduanya harus selalu menjaga kesucian perjanjian tersebut. Demikian pula dalam Pentateukh, walaupun

\footnotetext{
${ }^{14}$ Weinfeld, "Berith", dalam: G. Johannes Botterweck dan Helmer Ringgren (eds.), Theological Dictionary of The Old Testament Vol. II (Michigan: Grand Rapids, 1974), 252-255.

${ }^{15}$ David F. Hinson, Sejarah Israel Pada Zaman Alkitab, 50.

${ }^{16}$ William Dyrness, Tema-tema dalam Teologi Perjanjian Lama, 95.

${ }^{17}$ Andrew E. Hill and John H. Walton, Survey Perjanjian Lama Terjemahan Tanpa Nama (Malang: Gandum Mas, 1998), 6

${ }^{18}$ Walter Eichordt, Theology of the Old Testament Vol. I (Philadelphia: Westminster, 1961), 39.
} 
tidak dituliskan secara implisit namun konsep hubungan perjanjian antara suami-isteri dapat ditemukan, dalam kalimat "Akulah Tuhan, Allahmu, adalah Allah yang cemburu ..." (Kel 20:5; Ul 5:9; Kel 34:14; Yos 24:19).19

Hubungan antara Allah dan umat-Nya terjadi dalam rangkaian kejadian-kejadian yang aktual. Hubungan ini bukan suatu ikatan yang sudah ada sejak mulanya dalam alam, tetapi ini suatu ikatan yang dibuat Allah melalui peristiwa-peistiwa khusus, dan inilah yang disebut dengan perjanjian. ${ }^{20}$ Tentu saja konsep tentang berith tidak terlepas dari langkah awal pemilihan oleh Allah terhadap Israel sebagai bangsa Allah. Dalam hal ini ungkapan pemilihan atas Israel sering sekali disebutkan dengan menggunakan kata bachar di dalam Perjanjian Lama, bachar dihubungkan dengan Yahweh yang memilih Israel menjadi umat-Nya. ${ }^{21}$ Bila kata bachar dihubungkan dengan seseorang, maka kata itu juga mencakup keseluruhan orang yang ada di sekitarnya. Pemilihan oleh Allah untuk melayani dan panggilan-Nya untuk memberkati baik pribadi maupun seluruh dunia menjadi tanda dari fase dalam berkat Tuhan yang melimpah. ${ }^{22}$ Pemilihan yang Yahweh lakukan kepada bangsa Israel sebagai umat-Nya sesungguhnya memiliki dimensi horizontal kepada seluruh bangsa di muka bumi, kata bachar adalah sebuah terminologi yang sangat indah untuk sebuah bangsa yang akan menjadi alat keselamatan yang universal.

\section{Makna Teologis Tanah dalam Perjanjian Lama}

Ayat pertama dalam Perjanjian Lama membicarakan tentang tanah, erets juga berarti tanah atau negeri. Sejak semula tanah telah diberikan kepada manusia. Kata erets sering sekali sebagai antithesis terhadap surga, menyangkut orientasi kehidupan dan peristiwa-peristiwa yang nyata di bumi. ${ }^{23}$ Mengikuti alur pemikiran kanonis bolehlah diperhatikan bahwa sejak mulanya tema tanah ini mendapat peran penting, terlepas dari interpretasi negative yang biasa ditawarkan, pernyataan Tuhan kepada Adam setelah kejatuhan ke dalam dosa, “...dengan bersusah payah engkau akan mencari rejekimu dari tanah seumur hidupmu” (Kej 3:17) menunjukkan bahwa tanah adalah ajang hidup manusia yang diciptakan itu. Dalam hubungannya dengan tanah Kanaan, Munther Isaac menyebutkan bahwa pemberian tanah Kanaan adalah pemulihan hubungan Allah dengan manusia sekaligus pemulihan manusia dengan tanah yang telah tercela pada masa penciptaan. ${ }^{24}$

\footnotetext{
${ }^{19}$ Weinfeld, “Berith”, 278.

${ }^{20}$ William Dyrness, Tema-tema dalam Teologi Perjanjian Lama, 107.

${ }^{21}$ Horst Seebass, "Bachar" dalam: G. Johannes Botterweck dan Helmer Ringgren (eds.), Theological Dictionary of The Old Testament Vol. II (Michigan: Grand Rapids, 1974), 74.

${ }^{22}$ Walter C. Kaiser, Teologi Perjanjian Lama Terjemahan Tanpa Nama (Malang: Gandum Mas, 2004), 117

${ }^{23}$ Magnus Ottoson, "Erets", dalam: G. Johannes Botterweck dan Helmer Ringgren (eds.), Theological Dictionary of The Old Testament Vol. I (Michigan: Grand Rapids, 1974), 390-391.

${ }^{24}$ Munther Isaac, From Land to Lands; from Eden to the Renewed Earth, (Cumbria: Langham Monographs, 2015), 154-155.
} 
Tuhan memberikan kepada umat Israel tanah Kanaan menjadi tempat kediaman dan milik pusaka bersama, sesuai dengan janji-Nya kepada bapa leluhur mereka dahulu. Peristiwa pemberian ini merupakan suatu pokok puji-pujian, dasar kepercayaan dan pengharapan bagi Israel, namun juga suatu amanat untuk menguduskan hidupnya sebagai umat Tuhan di dalam tanah milik Tuhan sendiri. Hal ini menunjukkan bahwa pemberian tanah perjanjian merupakan suatu "pokok kepercayaan", yakni salah satu pasal dari "credo" umat Israel yang dipegang sepanjang masa. ${ }^{25}$

Beberapa teks tua mengaitkan pemilihan Israel sebagai umat dengan janji memberikan tanah yang pada waktu itu masih disebut dengan "tanah Kanaan" (Kej 23:2), "pegunungan orang Amori" (Ul 1:7), atau "tanah orang Het" (Yos 1:4). Tanah itu diduduki beberapa bangsa yang lebih besar jumlahnya dan lebih kuat dari bangsa Israel, yakni tujuh bangsa menurut Ulangan 7:1 (Het, Girgasi, Amon, Kanaan, Feris, Hewi, Yebus) atau sepuluh bangsa menurut Kejadian 15:19-21 (Keni, Kenas, Kadmon, Het, Feris, Refaim, Amori, Kanaan, Girgasi, Yebus). Kepada Abraham leluhur bangsa Israel janji demikian dijanjikan: "Pergilah dari negerimu dan sanak saudaramu dan dari rumah bapamu ini ke negeri yang akan Kutunjukkan kepadamu” (Kej 12:1; bnd. 15:7).

Tuhan berjanji memberikan "tanah" untuk Abraham dan keturunannya. Bila kadang-kadang disebutkan hanya untuk "keturunan" Abraham (Kej 17:18), tentu maksudnya bukan Abraham tak termasuk, melainkan janji itu berlaku bahkan sampai keturunannya (Kej 17:8). Janji memberikan tanah juga diberikan untuk Ishak (Kej 26:3) dan Yakub berikut keturunannya (Kej 28:13). Terlibatnya keturunan dari Abraham, Ishak, dan Yakub sebagai pewaris tanah perjanjian mengisyaratkan bahwa janji pemberian tanah itu tidak digenapi dalam waktu dekat sewaktu mereka hidup, sebagaimana juga janji Tuhan untuk menjadikan Abraham sebagai bangsa besar tidak terjadi dalam satu generasi (Kej 12:2; 17:2). Sekalipun janji itu sudah pasti, semasa hidup Abraham tanah itu belum bisa diklaim sebagai miliknya. Alkitab menggambarkan Abraham sebagai "orang asing dan pendatang" (Kej 23:4; 35:27). Yakub juga menggambarkan dirinya di depan Firaun seperti Abraham dan Ishak, mengembara sebagai orang asing (Kej 47:9). Dengan berpindah-pindah dari satu tempat ke tempat lain tanpa kediaman tetap, leluhur Israel hiidup dalam ketegangan antara janji dan pemenuhannya. Mereka selalu mengharapkan pemenuhan janji itu supaya tidak terus mengembara. ${ }^{26}$

Seperti yang dikutip Stanojevic, Brugemann menyebutkan bahwa tanah perjanjian ini bukan sekadar ruang tetapi lebih kepada tempat. Menurutnya, "ruang" dapat saja dipahami sebagai suatu yang terbuka dan netral, tetapi tidak demikian dengan "tempat" yang dapat dimengerti sebagai ruang yang memiliki sejarah dan makna khusus, di sana terjadi peristiwa-peristiwa penting, kata-kata penting yang diucapkan, dan di mana sumpah serta janji dikumandangkan. Sehingga tanah yang ditempati Israel bukan

\footnotetext{
${ }^{25}$ Christoph Barth, Theologia Perjanjian Lama 2 (Jakarta: BPK Gunung Mulia, 2001), 10.

${ }^{26}$ Yehezkel Kaufmann, The Religion of Israel (Pennsylvania, tanpa tahun), 241.
} 
semata ruang, tetapi tempat yang menyediakan identitas hubungan dengan Yahweh, si Pemberi tanah. ${ }^{27}$

Sehingga dengan demikian dapatlah dikatakan bahwa Israel dan tanah merupakan dua entitas tak terpisahkan dalam Perjanjian Lama. Sejarah bangsa Israel di Perjanjian Lama boleh dikatakan berpusat pada tanah perjanjian (Tanah Kanaan) yang kelak disebut "negeri Israel" (erets yisrael) atau "tanah yang kudus" (holy land). Bangsa Israel selalu, kapan dan dimanapun, merindukan tanah itu sebab di situlah Tuhan terlibat dengan mereka, Dalam nubuat tentang pembuangan pun masih terselip janji Tuhan untuk membawa pulang bangsa Israel kembali ke tanah (Yes 14:1-2). Nabi Yeremia menyebut peristiwa kembalinya Israel itu sebagai keluaran kedua (Yer 6:14-15; 23:7-8, bnd. Yeh 28:25; 36:8-15).

Keyakinan bahwa Israel akan kembali dari pembuangan ke tanah perjanjian tercermin dari nubuat Yehezkiel. Ia menggambarkan inisiatif Tuhan memulihkan dan membawa bangsa Israel pulang (Yeh 36:22-28; 37:25) dan pada waktu itu juga ada pembagian batas-batas tanah seperti pada zaman Yosua (Yeh 47:13 - 48:29). Akhirnya, kesetiaan Tuhan terbukti dan bangsa Israel kembali dari pembuangan berkat dekrit yang dikeluarkan Raja Koresy yang mengizinkan mereka pulang (Ezra 1:1-4). Sayangnya, kehidupan mereka di tanah masih terbelit problem-problem lama. Lalu, Nehemia dan Ezra mengadakan langkah-langkah pemurnian seperti larangan kawin campur (Ezra 9:10-15; 10:10-11,44; Neh 13:23-26), konsekuen menguduskan hari Sabat (Neh 13:15-18), berbuat adil dan baik kepada yang tertindas (Neh 5:3-11).28 Pendudukan Tanah Perjanjian, dibuang dari sana dan kembali lagi, semua peristiwa itu menyimpan kenangan iman bagi bangsa Israel. Tanah adalah ajang, pergumulan iman bangsa Israel, sekaligus di sinilah letak jati diri Israel sebagai umat. Sebab itu, sejarah Allah dalam Perjanjian Lama sebenarnya bukan cuma Allah dengan umat-Nya, tetapi lebih tepat lagi adalah: Allah dengan umat-Nya di tanah. ${ }^{29}$

Secara teologis jelas, umat Israel percaya bahwa Tuhan memerintah atas seluruh dunia, maka menurut kepercayaan itu tanah Kanaan yang sangat kecil itu pun merupakan salah satu wilayah kuasa-Nya. Inilah yang menjadi dasar keseluruhan aktivitas umat Israel di tanah Kanaan. Tanah diberikan untuk memenuhi kebutuhan hidup sehari-hari keluarga-keluarga Israel. Pada tanahlah tergantung hidup mereka. Tuhan sendiri mengatur pembagian tanah lewat undi (Yos 14:1-2; 18:1-10) yang luasnya untuk masing-masing keluarga tidak sama tergantung besar kecilnya keluarga (Bil 26:34; Yos 13-19). Lewat para pemimpin umat pada waktu itu, Tuhan telah membagi-bagi tanah dengan adil (Ul 19:14; Ay. 24:2; Ams 23:10). Maka, batas-batas tanah keluarga sudah tetap dan tidak boleh digeser-geser (Ul 19:14; bnd. Ams 22:28;

\footnotetext{
27 Durdica Stanojevic, The Promised Land: Hermeneutical And Theological Approach. Contemporary Ecotheological Readings, (Thessaloniki: Aristotle University Of Thessaloniki, 2014), 50.

${ }^{28}$ H.H. Rowley, The Old Testament and Modern Study (Oxford: Oxford University Press, 1961), 297-298.

${ }^{29}$ Walter C. Kaiser, Teologi Perjanjian Lama (Malang: Gandum Mas, 2004), 139.
} 
Ayb 24:2). Barangsiapa menggeser batas tanah orang lain, ia akan terkutuk (Ul 27:17). Setiap penggusuran dalam Perjanjian Lama, sekalipun dilakukan oleh penguasa dan sah secara hukum kerajaan, tetap melawan hukum Tuhan (Hos 5:10). ${ }^{30}$

Namun demikian kemakmuran tanah bisa membuat orang menjadi tinggi hati, lupa diri, dan tak lagi bersandar pada Tuhan (Ul 8:11-20). Tanah dianggap otomatis mengeluarkan hasil-hasil yang baik, asalkan orang rajin dan pintar (ay. 17). Mereka lupa bahwa Tuhanlah yang sebenarnya memberikan mereka "kekuatan untuk memperoleh kekayaan" (ay. 18). Maka godaan yang paling berbahaya hidup di tanah yang diberkati adalah berpaling dari Tuhan yang memberikan tanah dan berpaling kepada dewa-dewa lain (ay. 19; bnd. Kel 20:4-5; Ul 6:14; 11:16). Israel dalam Perjanjian Lama sering melupakan Tuhan, berpaling kepada dewa-dewi kesuburan dan berpaling dari Allah sumber kehidupan.

Maka, penting sekali beribadah kepada Tuhan dan tidak jatuh ke dalam penyembahan berhala. Untuk itu bangsa Israel harus selalu ingat bahwa mereka dulu dibebaskan dari belenggu perbudakan Mesir dan dipimpin melewati gurun yang luas mengerikan tanpa kekurangan sedikit pun. ${ }^{31}$ Wajarlah kini mereka hanya memberikan penghormatan dan loyalitas yang tertinggi kepada Tuhan dan bukan kepada yang lain. Tanah diberikan supaya umat memiliki relasi yang permanen dengan Tuhan. Tanah merupakan bukti adanya hubungan istimewa itu. Tuhan tidak malu menyebut bangsa Israel sebagai "anak-Ku yang sulung" (Kel 4:22; bnd. Ul 32:5-6, 18-19 dan secara kiasan dalam Ul 8:5). Pemberian tanah kepada Israel berfungsi sebagai bukti hubungan antara Allah dan Israel. Israel mengetahui mereka adalah umat Allah karena Ia telah memberikan kepada mereka tanah-Nya, pemberian itu membuktikan hubungan yang terkait kepada perjanjian dengan Abraham dan perjanjian Sinai dengan seluruh bangsa itu. ${ }^{32}$ Ketika bangsa Israel dibebaskan dari perbudakan Mesir, kejadian itu digambarkan sebagai mewarisi tanah Kanaan, seperti mewarisi harta orangtua. "Akulah Tuhan, Allahmu, yang membawa kamu keluar untuk memberikan kepadamu tanah Kanaan, supaya Aku menjadi Allahmu" (Im 25:38).

Sebagai anak, bangsa Israel mempunyai bagian (kheleq) di tanah Tuhan (Yos 22:25, 27), sebidang tanah yang disebut warisan (nakhala) atau "milik pusaka" (Ul 4:21, 38; $12: 9 ; 15: 4 ; 19: 10 ; 26: 1)$. Menarik sekali, dalam cerita tentang keluaran, Allah menyebut Israel sebagai "anak-Ku yang sulung" (Kel 4:22), yang ingin dibebaskan-Nya dari ketertawanan dengan maksud membawanya ke tanah perjanjian. Mengapa anak sulung Allah merana di tanah asing sementara warisannya menanti? Bahasa warisan dalam konteks hubungan anak dan orangtua ini juga mengandung arti bahwa sang anak sulung tidak perlu terus merana karena warisan siap untuk dimiliki. Bahasa warisan seperti itu sedikit jarang ditemukan dalam kitab Keluaran (bnd. Kel 15:17; 32:13), tetapi muncul dalam kitab Ulangan. Kata yang berarti "menduduki" atau "memberikan kepada"

\footnotetext{
${ }^{30}$ Christoph Barth, Theologia Perjanjian Lama 2 (Jakarta: BPK Gunung Mulia, 2001), 27.

${ }^{31}$ Yehezkel Kaufmann, The Religion of Israel, 242.

${ }^{32}$ Christopher Wright, Hidup Sebagai Umat Allah, 53.
} 
biasanya dipakai dalam hubungan dengan warisan. Kadang-kadang tanah itu langsung disebut warisan (mis. Ul 4:21; 4:38 dsb.), karena itu Israel adalah pewarisnya. Rasa sakit yang mendalam bagi orang Yahudi selama masa pembuangan adalah kehilangan tanah mereka di samping kehilangan kerajaan dan kehilangan kota Yerusalem. Janji pemulihan orang Israel dikaitkan secara implisit dengan pemulihan tanah mereka. Nabi-nabi Perjanjian Lama menegaskan bahwa tanah adalah milik Allah dan bahwa walaupun Allah telah memberikan tanah perjanjian, hak mereka untuk memilikinya dapat dihapuskan. Hukuman Allah atas Israel karena mencemarkan Kesucian Nama Allah adalah dengan mengambil tanah mereka (Yeh 36:21-23). Pemulihan tanah itu hanya dimungkinkan dalam suatu masyarakat yang berlaku adil terhadap semua warganya. Selanjutnya, pemulihan tanah adalah untuk kemuliaan nama Allah. Dalam Yeh 47:22-23, kita belajar bahwa orang asing juga mempunyai hak-hak tertentu atas tempat tinggal. ${ }^{33}$

Mereka yang tinggal sesudah pembuangan disebutkan adalah orang-orang yang termiskin dari yang termiskin. Mereka kehilangan kendali atas tanah mereka dan menjadi subjek penguasaan dan pemerasan para pemimpin. Kendati mereka hidup dengan mengandalkan tanah itu, hilangnya kekuasaan pengawasan atas tanah itu merupakan rasa sakit yang sama dengan pemindahan fisik dari rumah mereka. Demikian juga dalam kehidupan sehari-hari orang Israel, tanah tak cuma bernilai ekonomis. Kehilangan tanah mengancam kedudukan sebagai anggota umat perjanjian, sebuah perkara yang amat serius. Maka, orang Israel tidak mau kehilangan tanah keluarga dan hal itu dijamin Taurat. ${ }^{34}$

Banyak sekali perintah Taurat masuk ke dalam kategori tanggung jawab yang berhubungan dengan tanah, langsung ataupun tidak langsung. Kepercayaan bahwa Allah mempunyai tanah dan menuntut pertanggungjawaban atas penggunaannya dari pemakainya sangat penting dalam etika Perjanjian Lama. Tidak ada apa pun yang dapat dilakukan dalam, atas, atau dengan tanah yang di luar lingkup pengawasan moral Allah. Dari persoalan utama tentang usaha mempertahankan wilayah nasional sampai ke masalah bagaimana orang memangkas pohon buah, setiap bidang kehidupan tercakup di dalamnya. Didasarkan atas prinsip seperti itu yang dinyatakan dengan sederhana, etika dan teologi Perjanjian Lama menjadi menyeluruh namun benar-benar praktis serta teliti. ${ }^{35}$

Taurat tidak tertarik pada ketaatan abstrak, tetapi pada cara hidup manusia di tanah milik Allah. Apakah maksud dan tujuan di belakang ikrar dan sumpah Allah menghibahkan tanah Kanaan kepada Israel? Tentu karena Allah berkenan memberkati umat-Nya. Inti berkat yang sesungguhnya bukanlah dalam hal makan dari hasil negeri

\footnotetext{
${ }^{33}$ Celia Deane-Drummond, Teologi dan Ekologi Terjemahan Robert P. Borrong (Jakarta: BPK Gunung Mulia, 2011), 29.

${ }^{34}$ Lihat Eun Suk Cho, Creation in the Book of Job: An Exegetical Essay on Job 3 from a Koren Perspective, dalam: Asia Journal of Theology 17, 2003, 43-44. Yehezkel Kaufmann, The Religion of Israel, 242.

${ }^{35}$ Walter Bruggemann, The Land: Place as Gift, Promise, and Challenge in Biblical Faith (Philadelphia: Fortress, 1977), 14-15.
} 
itu (Yos 5:12) atau sebatas dapat lama di tanah yang diberikan Tuhan (bnd. Kel 20:12), tetapi inti berkat yang hendak disampaikan kepada umat itu terletak di dalam hidup mereka selaku umat Tuhan. Membangkitkan, menggerakkan, menggiatkan mereka kea rah itu, justru itulah yang dikehendaki Allah. Pemberian tanah Kanaan hendaknya menyediakan ruang hidup, tetapi melebihi itu: ruang hidup yang berumat. Tanah itu hendaknya menjadi motivator yang mampu mengembangkan kehidupan Israel sebagai umat-Nya. Negeri sebagi tempat pembinaan umat. ${ }^{36}$

\section{Manusia dan Tanah: Damai Sejahtera Bagi Segenap Ciptaan}

Dengan ini dapatlah dilihat, sebenarnya pemilihan Israel tidak cuma berbicara tentang asal-mula bangsa, permulaan bertemunya Allah dengan Israel, tetapi juga tentang pemeliharaan Tuhan terhadap umat pilihan-Nya. Israel tidak pernah eksis dari dirinya sendiri, tetapi selalu bergantung kepada yang memilihnya dan Penciptanya. Hal ini sejalan dengan apa yang diutarakan oleh Stanojevic yang menyatakan bahwa ekoteologis Kristen bergerak atas tiga aras utama: tindakan Allah dalam penciptaan, tanggung jawab istimewa manusia memelihara ciptaan, serta peran gereja dalam dogma dan praksis ekologis. ${ }^{37}$

Kekuasaan Allah atas dunia tidak hanya berlaku pada waktu penciptaan pada awalnya, tetapi terus berlangsung dalam tegaknya dunia. Hubungan kebergantungan ini tidak bersifat narsistik sebab dunia dijadikan bukan demi kesenangan Tuhan, melainkan agar di dalam dunia tumbuh keselamatan dan keadilan (Yes 45:8). Konsekuensi dari dunia ciptaan yang baik dan diberkati adalah keselamatan dan keadilan itu masih dalam bentuk potensi yang harus diaktualisasikan. Kemajuan peradaban dan teknologi dimungkinkan karena dunia berkembang dalam batas-batas potensi yang ada ini. Potensi-potensi yang baik ini tidak berdiri sendiri, tetapi bergantung pada Sang Pencipta dan dengan cara inilah Ia menopang kelangsungan dunia. ${ }^{38}$

Terbentuknya lahan-lahan kritis yang semakin luas di Pulau Jawa dan banyak tempat lain di Indonesia tentu dikarenakan sabat untuk tanah tak dikenal. Manusia tidak menyadari tanggung jawabnya terhadap alam, sebagi bagian dari perjanjian-Nya dengan Sang Pemilik Tanah, ia dengan sesuka hati dan ketidakberpuasannya mengeksploitasi alam sebesar-besarnya. Akibat lebih lanjut, keseimbangan alam terganggu. Manusia memakai perintah "menaklukkan" bumi tanpa menyadari bahwa ia hidup di atas tanah yang ia "taklukkan" itu. ${ }^{39}$ Bahkan lebih dari itu, dimensi teologisnya adalah manusia seharusnya hidup untuk merawat tanah yang dipinjam dari Sang Pemilik, tanah sebagai anugerah tanda perjanjian Allah dengan umat-Nya. Bahkan bila lebih teliti melihat analisis eksegetis dalam berkat untuk "menaklukkan" (kibsuha) bahwa kata ini hanya menunjuk kepada "pengusahaan" bumi/tanah. Dengan ini sama sekali tidak

\footnotetext{
${ }^{36}$ Christoph Barth, Theologia Perjanjian Lama 2, 41.

37 Durdica Stanojevic, The Promised Land: Hermeneutical And Theological Approach. Contemporary Ecotheological Readings, (Thessaloniki: Aristotle University Of Thessaloniki, 2014), 95.

${ }^{38}$ Christoph Barth, Theologia Perjanjian Lama 2, 69-70.

${ }^{39}$ Robert P. Borrong, Etika Bumi Baru (Jakarta: BPK Gunung Mulia, 2011), 227.
} 
ada hak manusia untuk "mengotori" ciptaan, mengeksploitasinya, bahkan malah harus menjaganya menjadi tetap dalam keadaan "bersih". ${ }^{40}$ Dengan demikian, kuasa yang diberikan Allah bukanlah suatu hal milik yang berarti hak menggunakan dan menyalahgunakan, melainkan hak memakai tanah ini dalam tanggung jawab terhadap Sang Khalik dan sesama manusia serta mahluk lainnya, dalam kesadaran bahwa manusia tidak dapat menciptakan hidup, tetapi hanya menerimanya sebagai berkat dari Allah sendiri. Ia hadir di bumi sebagai alat Pencipta-Nya untuk menjaga kelangsungan hidup ciptaan-ciptaan yang lain, menjaga keseimbangan alam dan mengupayakan kelestariannya.

Dalam seluruh Perjanjian Lama ada hubungan berpautan antara manusia dan tanah. Keduanya terikat bersama-sama dalam hubungannya dengan Allah. Dalam Yeremia 23 dan 24 misalnya, hukuman terhadap manusia dihubungkan dengan ketandusan tanah!41 Bukankah seharusnya kita sekarang menjadi layak untuk merenungkan kerusakan ini sebagai sebuah sikap hidup yang menjauhi ikatan perjanjian dengan Tuhan dalam mengupayakan bumi ini?

\section{Kesimpulan}

Seharusnya manusia menjadikan tanah sebagai anugerah yang tetap harus dipertanggungjawabkan kembali kepada Siapa yang menghibahkan kepadanya? Dalam konteks pemeliharaan Allah, Ia menempatkan manusia pada posisi mitra. Manusia diikutsertakan dalam pemeliharaan-Nya atas tanah dengan jalan meneruskan penciptaan dalam kapsitasnya sebagai co-creator. Manusia sebagai co-creator dalam melanjutkan karya pemeliharaan terhadap tanah dan dunia ini, mempunyai tugas untuk membawa seluruh penciptaan kepada langkah selanjutnya dalam proses menuju kesempurnaan. Dengan akal budi dan hati nuraninya, manusia dimungkinkan untuk mengembangkan dunia ciptaan, termasuk berlaku adil dan murah hati kepada setiap ciptaan lain yang tertindas. Tanah juga butuh istirahat (Im 25:1-13). Pada tahun ketujuh tanah tidak ditanami dan tidak dituai. Ketika tanah tak dipaksa untuk berproduksi, humus tanah kembali dan tanah siap ditanami lagi. Umat harus selalu diingatkan bahwa tanah berasal dari Allah dan kehidupan di situ harus dikelola dengan penuh tanggung jawab sesuai ketentuan Pemilik tanah. Bila taat, masa depan terjamin. Bila memberontak, segala yang baik akan pergi. Allah menyerahkan kepada manusia hak pemerintahan dan pemeliharaan atas bumi, tanah, dan segala sesuatu yang ada di dalamnya. Kemampuan tersebut membuat manusia sebagai wakil Allah. Namun demikian bukan berarti manusia dapat membuat peraturan sesukanya sendiri, karena segala sesuatu dipertanggungjawabkan kepada Allah.

\footnotetext{
${ }^{40}$ G. Andre, "kabas", dalam: G. Johannes Botterweck dan Helmer Ringgren (eds.), Theological Dictionary of The Old Testament Vol. VII (Michigan: Grand Rapids, 1974), 52.

${ }^{41}$ Celia Deane-Drummond, Teologi dan Ekologi, 29.
} 


\section{Referensi}

Alexander, Desmond dan David W Baker. Dictionary Old Testament: Pentateuch,

Leichester: Intervarsity Press, 2008.

Barth, Christoph. Theologia Perjanjian Lama 1, Jakarta: BPK Gunung Mulia, 2008.

Barth, Christoph. Theologia Perjanjian Lama 2, Jakarta: BPK Gunung Mulia, 2001.

Binson, John. The World of the Old Testament, London: Scripture Union, 1988.

Borrong, Robert P. Etika Bumi Baru, Jakarta: BPK Gunung Mulia, 2011.

Botterweck, G. Johannes dan Helmer Ringgren. peny. Theological Dictionary of The Old

Testament I-VII, Michigan: Grand Rapids, 1974.

Boyce, Richard N. The Cry to God in the Old Testament, Atlanta: Scholars, 1988.

Bruggemann, Walter. The Land: Place as Gift, Promise, and Challenge in Biblical Faith,

Philadelphia: Fortress, 1977.

Childs, Brevard S. Memory and Tradition in Israel, London: SCM Press, 1961.

Cho, Eun Suk. Creation in the Book of Job: An Exegetical Essay on Job 3 from a Koren

Perspective, dalam: Asia Journal of Theology 17, 2003.

Croft, Steven. The Identity of the Individual in the Psalms, Sheffield: Sheffield Academic Press, 1987.

Darmawijaya, Jiwa dan Semangat Perjanjian Lama, Yogyakarta: Kanisius, 1992.

Douglas, J.D. peny. Ensiklopedi Alkitab Masa Kini 1, Jakarta: Yayasan Komunikasi Bina Kasih/OMF, 2000.

Drummond, Celia Deane. Teologi dan Ekologi Terjemahan Robert P. Borrong, Jakarta; BPK Gunung Mulia, 2011)

Dyrness, William. Tema-tema dalam Teologi Perjanjian Lama, Malang: Gandum Mas, 2014.

Eichrodt, Walther. Theology of the Old Testament Vol. I, Philadelphia: The Westminster Press, 1960.

Elisson, H.L. The Message of the Old Testament, Michigan: Grand Rapids, 1969.

Hill, Andrew E. dan John H. Walton, Survey Perjanjian Lama, Malang: Gandum Mas, 1998.

Hinson, David F. Sejarah Israel Pada Zaman Alkitab terjemahan Mawene, Jakarta: BPK Gunung Mulia, 2000.

Isaac, Munther. From Land to Lands; from Eden to the Renewed Earth, Cumbria: Langham Monographs, 2015.

Kaiser, Walter C. Teologi Perjanjian Lama, Malang: Gandum Mas, 2004.

Karman, Yonky. Bunga Rampai Teologi Perjanjian Lama, BPK Gunung Mulia, Jakarta, 2007.

Kaufmann, Yehezkel. The Religion of Israel, Pennsylvania, tanpa tahun.

Preuss, H.D. Old Testament Theology Vol. I, Edinburg: T and T Clark, 1991.

Rowley, H.H. The Old Testament and Modern Study, Oxford: Oxford University Press, 1961.

Stanojevic, Durdica. The Promised Land: Hermeneutical And Theological Approach. Contemporary Ecotheological Readings, Thessaloniki: Aristotle University Of Thessaloniki, 2014.

Vriezen, Th.C. Agama Israel Kuno. Jakarta: BPK Gunung Mulia, 2000.

Wahono, Wismoady. Di Sini Kutemukan, Jakarta: BPK Gunung Mulia, 2000.

Waltke, Bruce K. An Old Testament Theology, Michigan: Grand Rapids, 2007.

Wright, Christopher. Hidup Sebagai Umat Allah Terjemahan Liem Sien Kie, Jakarta: BPK Gunung Mulia, 1995. 